\title{
DIE ONTSTAAN OF WORDING EN WESE VAN TAAL
}

Dit is die lot gewees van die taalstudie en taalbeoefening waaruit die Westerse Taalwetenskap ontwikkel het en selfs sy huidige inhoud en vorm aan dank of wyt dat dit val, die begin af deur spekulasie en filosofie oorheers is. So ver die geskiedenis van die taalstudie ons in die verlede terugvoer, 
is dit die filosowe van watter soort, rigting of skool ookal, wat hulle met die probleem van die oorsprong en wese van taal besig gehou het. Die filosofie het vir hom die probleem toegeëien, die filosofie en die spekulasie (as dit nie filosofie was nie) het feitlik dermate die hele vraagstuk gemonopoliseer dat vandag nog ons taalbeskouing en taalbeoefening beheers word deur die filosofie en steun op grondslae deur die filosofie gelê en geformuleer. Maar meer nog: wat vandag deurgaan vir suiwer Taalwetenskap of Linguistiek is ' $n$ mengsel van allerlei filosofiese spekulasies en suiwer taalmateriaal, taalgegewens en verskynsels. Vanuit suiwer linguale standpunt gesien het die filosofie regstreeks en onregstreeks die Taalwetenskap 'n pseudowetenskap gemaak en is die oorsaak dat linguiste oor taal praat en skryf, taal bestudeer en hulle sogenaamd wetenskaplik daarmee besighou sonder om eenstemmig te weet wat presies die objek van hulle wetenskap is. Dié filosofie het by die tenvolle gewaardeerde winste en voordele wat dit vir die taalstudie gebring het, eerlikwaar tog die suiwere taalstudie benadeel, gestrem en beslis op sulke dwaalweë gevoer dat linguiste as ' $t$ ware magteloos worstel om van die filosofiese oorheersing los te kom. Met die ,grammatika" en die "grammatiese taalbeskouing" sit die taalwetenskap en veral die taalonderwys letterlik opgeskeep: dis grootliks verkeerd, dis verouderd omdat dit feitlik deur en deur illinguisties gefundeer is en 'n illinguistiese terminologie het wat werk met 'n illinguistiese want filosofiese begrippestelsel.

Hierdie oorheersing deur die filosofie-dikwels nie filosofie nie maar suiwer metafisiese spekulasie of fantastiese dromery-is verklaarbaar. Immers, ,taal" of wat vir taal aangesien word, is so'n algemene verskynsel, het so deur alle tye heen by alle mense bestaan en is so algemeen gebruik en so alledaags, so doodgewoon, en bekend dat enigeen as ' $t$ ware vir jou wil en kan sê wat taal is, waar dit vandaan kom en hoe dit ontstaan. Altans iedereen sou dáárom die reg hê om dit te doen. Die enigste vereiste is: hy moet ' $n$ bietjie normale gesonde verstand hê. Dus enigeen wat 'n bietjie wil of kan filosofeer of spekuleer kan maar gerus probeer. Daarby lê dit in die aard van die verskynsel, ,taal" dat wie ook al dit mag probeer! Taal voer ons na of verbind ons met die Godewêreld: die gode moet ook taal hê. Vir ons het God taal, want Hy ,spreek" tot ons. Taal bestaan uit ,woorde" en deur die ,woord" te spreek het God die skepping in aansyn geroep. Die „Woord" van Hom het in Christus-gestalte verskyn. Daarom sou dit ook die reg en die taak van die Teoloog wees om die oorsprong en wese van Taal te verklaar. En baie Teoloë hét dit probeer doen. Maar taal is vir die mens tog by uitstek middel vir sy geesteswerksaamhede, 
'n bewussynsmiddel一daarom kan en moet die Psigoloog vir ons die probleem oplos. En baie Psigoloë het dit gedoen, uit al die psigologiese skole en rigtings. Maar Pedoloë en Pedagoë het veral met die taal te doen, daarom is dit ook hulle reg en taak om aan die wêreld te moet sê wat taal is en waar dit vandaan kom of hoe dit ontstaan, hoe dit ontwikkel veral by die kind. Die studie van die Kindertaal is veral die terrein van die Pedagoog en die Pedoloog. En as taal dan net of volgroeid by die mens voorkom, is dit dan nie veral die terrein van die Antropoloë nie? As taal dan ook rasmatig, nasiematig, en groepmatig voorkom oor die ganse aarde, is die oplossing van die probleem dan nie by uitstek die reg en die taak van die Etnoloë nie? En ook Etnoloë hét dit probeer doen. En as Archeoloë veral met die oudste taaloorlewinge te doen kry en hulle moet ontsyfer-moet hulle mos die oorsprongsprobleem oplos. As groepvorming, nasievorming, rasontwikkeling dan eintlik sosiale verskynsels is en taal so'n belangrike onderskeidings- en saambindings-verskynsel en -middel is, is dit dan nie die reg en taak van die Sosioloog nie? En watter Sosioloog het dit nog nie probeer doen nie? So sterk is hierdie sosiale, nasionale, groepmatige en rasmatige aspek van die ,taal" as verskynsel in sy vorm en in sy gebruik dat mens vandag feitlik geen linguistiese werk, gesaghebbend al dan nie, kan ter hand neem nie, óf dit beskou en aanvaar taal as 'n ,sosiale verskynsel", wat moes voortgekom het eers ná daar 'n „gemeenskap", hetsy van diere, hetsy van vermenslike wesens, bestaan het, uit die drang van sosiale behoeftes en verhoudinge vir bewerkstelliging van samewerking en vir behartiging van sosiale doeleindes. Eminente taalkundiges aanvaar dan ook die verklaringe van Sosioloë oor die oorsprong en wese van taal wat gegroei het uit die filosofie en in die filosofie wortel as gesaghebbend. Dit sal vir iedereen duidelik wees dat daar talle verklaringshipoteses of teorieë moet bestaan. En alger bedoel om dieselfde verskynsel te verklaar. Hulle verskil van mekaar nie slegs gradueel nie, maar dikwels fundamenteel, sodat „taal" telkens volgens die een hipotese iets geheel anders is as volgens die ander-al erken almal die een kenmerk dat taal 'n ,Klankverskynsel”' is, in bepaalde vorme, in sover sommige dit nie selfs sien as 'n skriftelike simboolstelsel nie. So het die poginge om die kernprobleem van die oorsprong en wese van taal vir die wetenskap op te klaar, 'n nuwe probleem geskep: watter van die verskiliende hipoteses is die regte een of watter waarheidsmomente in die verskillende hipoteses is so bruikbaar om daaruit dan eindelik tot die enigsmoontlike te lei. Ook hieroor verskil teoretici en selfs die Linguiste onder mekaar. Want ook Linguiste het hulle eindelik gewaag aan 'n oplossing van die probleem. Maar die ongelukkige toestand 
is dat hulle hulle laat bind en knel deur die tradisie of laat beïnvloed deur of hipoteses van die Filosowe, die Psigoloë, die Teoloë selfs, die Antropoloë die die Sosioloë. Die tyd het egter aangebreek dat die Linguis vir hom die reg opeis om die oorsprong en wese van sy studieobjek self te verklaar, net soos bv. die Chemikus syne, die Botanikus syne en elke ander wetenskaplike syne. Die verskil is net dit: die Chemikus, die Botanikus, die Soôloog, die Geoloog, die Astronoom, bv. se vorsingsobjek is nie sy eie maaksel nie, dit bestaan buite hom en het ontstaan sonder sy toedoen. Met die Linguis is dit anders: sy objek is sy eie maaksel, dit bestaan in hom, deur hom, vir hom, nie buite hom nie en nie sonder hom nie.

Dit is onmoontlik om hier die verskillende teorieë of ook maar enkeles van hulle te gee en krities te ondersoek met die oog op 'n moontlike keuse. Ons wil daarom die verskillende teorieë saamvattend rangskik en in vier groepe onderbring volgens die enigste vier moontlikhede wat kan bestaan om die oorsprong van die taal en daaruit die wese daarvan te verklaar. Al vier die moontlikhede is oor en oor vanuit verskillende gesigspunte geeksploïteer en die teorieë bevat ál die moontlike uitkomste. Die enigste vier moontlikhede-of die vier enigste moontlikhede-is die volgende:

1. taal kan uit die bo- en buitemensmenslike geesteswêreld d.i. godewêreld vandaan kom, klaar gemaak in die mens se mond gelê, aan hom geopenbaar of die mens kan deur goddelike mag só bewerktuig gewees het om ' $n$ taal te maak soos feitlik aan hom gedikteer of ingegee is;

2. dit kan uit die natuurlike wesendheid van die synsdinge of -verskynsels wat die mens ervaar en belewe, die mens toestraal of ingegee word -dus sou die taal uit die natuur self kon ontstaan;

3. dit kan uit die dierewêreld sy ontstaan en herkoms hê: uit diergeluide of dierskreeue ontwikkel het, by die mens deur sy geluide en klanke eers tot voltooiing gekom;

of 4. taal kan net dit wees wat by mense voortkom en het dus by, uit en deur die mens ontstaan. Om 'n duideliker insig in en beknopter oorsig oor die verskillende teorieể te verkry wil ons hulle volgens hierdie moontlikhede indeel en respektiewelik karakteriseer as (a) die teogenetiese, (b) fusiogenetiese, (c) die soobgenetiese en (d) die antropogenetiese.

(a) Die teogenetiese is deur baie mense die eeue deur in verskillende vorme as werklikheid aanvaar en as waarheid gestel en verdedig. Selfs vandag nog is daar ernstige mense wat geen ander verklaring of oplossing van die probleem kan vind nie: God het die taal aan die eerste mens, Adam, gegee, in sy mond gelê of aan hom geopenbaar. So'n, of enige ander vorm van teogenetiese verklaring vind nie alleen nêrens in die Bybel steun nie 
maar is selfs in stryd met wat daar wel oor taal gegee word in Gen. 2:19; 20. In geen vorm is enige teogenetiese teorie aanvaarbaar nie. Dit plaas die probleem buite die Linguistiek: in die Paradys of op Parnassus of Olympus!

(b) Die fusiogesnetiese beskouingswyse wortel in 'n soort natuurmistiek, 'n vorm van primitiewe natuurbelewing wat ook in die mythos vorm neem. Soiets is deur die Griekse filosowe gerasionaliseer in die phusis-teorie, suiwer spekulatief en soms fantasties. Deur Aristoteles veral het dit, wél gewysig en aangepas in die thesis-teorie, sy finale toepassing gekry in die logiese ontleding van die taal, self gesien as 'n natuurwesentlike, rasioneel-logiese stelsel waarvan die $\sin$ as rasionele eenheid, as logiese denkeenheid die primêre taaleenheid is. Die "woord" is hiervolgens geen outonome taaleenheid, dit is 'n logiese abstraktuur as element var die sin. Op hierdie vorm van fusiogenetiese teorie is ons logies-kategoriese, klassisistiese grammatika en taalinterpretasie gevestig. Vandag nog word die taalwetenskap en taalonderwys hierdeur heheers en daardeur gerelegeer tot 'n pseudo-wetenskap.

Die verskillende nabootsteoriee is maar in wese gewysigde vorme van die fusiogenetiese moontlikheid, soos o.a. die sg. bow-wow-teorie en die ding-dong-teorie. In watter vorm hulle ook al verskyn..... geerieen van hulle is aanvaarbaar nie.

(c) Die sozgenetiese teorieë wissel vanaf die wat by die dier ook „taal”, dieretaal, omgangstekens, heenwysingstekens, simbole aantref, al is die tekens dan ook maar die begin, die voorstadium van wat by die mens eers taal word, tot die wat dan by die mens die suiwerste vorm van die volgroeide simboolstelsel in die ,woorde" sien. Die voorstanders van hierdie beskouingswyse moet dus 'n ,voortaallike" ontwikkelingstrap aanneem, en, getrou aan die ewolusieteorie, dus ook 'n ,voormens"-'n ,homo alalus", der "Sprachlose Urmensch" wat dan die kameraad en gesél van 'n , animal loquens" moes gewees het. Die homo alalus dan "gewon homo sapiens en homo sapiens gewon homo loquens". Taal het dus 'n dierlike herkoms en wat ons vandag nog by diere aantref, die erfenis van die voorhistoriese, die oerdier, moet vir die Linguistiek nog navorsingsmateriaal wees om die probleem van die taaloorsprong en taalwese te verklaar. Watter vorm die soögenetiese teorieë ookal mag aanneem, hulle bied vir die Linguistiek 'n steriele fiksie-alles berus op spekulasie, aprioristiese skepping of hipotetiese stelling van nie-bestaande of, -bewysbare dinge. Die bestaan van ' $n$ taalof spraaklose oerwese is nie bewysbaar nie, omdat dit nie bestaanbaar is nie. Daar is nie ' $n$ verskynsel denkbaar of selfs fantaseerbaar tussen die 
dierskreeu en die menslike taal nie. Selfs hier is daar 'n onoorbrugbare kloof tussen dier en mens, tussen die mees gedifferensieërde skreeu of geluid van die geleerdste antropoïde sjimpansee en die mees primitiewe vorm van mensetaal: nie slegs 'n kloof tussen vorm en vorm nie, maar'n kloof tussen ontstaan en ontstaan, tussen wese en wese, tussen funksie en funksie. Enige vorm van soögenetiese verklaring wat uitgaan van, steun op, aansluit by of selfs 'n verwante analogiese parallel vind met die dier, dierskreeu, diergeluid, dierhandeling of diergedraging, moet in hierdie kloof tussen taalmens en taallose dier, tussen mensetaal en dierskreeu te pletter stort. Hulle steun op ,fantasievolle Erfindungen”, denkbeeldighede wat buite die gebied van die taal en die Linguistiek lê.

(d.) Die enigste moontlikheid wat nou nóg oorbly, is die antropogenetiese, die wat taal as 'n puurmenslike verskynsel sien en as sodanig aanvaar. Dis egter onmoontlik om van die vele teorieë hier 'n opsomming of selfs 'n goeie oorsig te gee. Daarom noem ons slegs 'n aantal van die belangrikstes: 1. verskillende nabootsingsteorieë wat aansluiting vind by die fusiogenetiese; 2. die lalteorie wat uitloop in die Kindertaalteorie; 3. die teorie van die prioriteit van sang of ritmiese klankuitinge by dans of werk, ens.-'n teorie wat tóg wortel in die soögenetiese wat teruggaan, soos o.a. by Darwin, Spencer en selfs Jespersen, tot die sang van voëls; 4 . die tekenteorie of simboolteorie: dat klanke geleidelik as tekens of simbole vir sake en verskynsels aangewend is; ook dit wortel in of gaan terug tot een of ander vorm van die ewolusionisties-soögenetiese teorieë; 5. die gebare-teorie wat eintlik, wortel in die instink-lewe en dus ook 'n soogenetiese grondslag het; 6. die teorieë wat taal sien as uitingsvorm of skepping van die menslike rede, die ratio, die verstand of as 'n uitings- en openbaringsmiddel van die psigiese vermoëns ens. 7. Dit bring ons nou by die moderne, die mees gangbare teorieë wat gekom het uit die Psigologie, die Sosiologie, die Antropologie en uit die Linguistiek self.

Wat ons hier wil beklemtoon is (i) dat feitlik deurgaans al die teorieë die taal aanvaar óf as 'n middel óf as 'n simbool: dis 'n uitingsmidel van gevoelens, gedagtes, ideë, begeertes, wense, strewinge, ens.; dis mededelingsmiddel van gevoelens en gedagtes; dis omgangs- of verkeersmiddel, dus ' $n$ sosiale verkeersmiddel, dis kontakmiddel vir die mens met sy omwêreld; óf dis 'n stelsel van klanksimbole waardeur of waarmee die spreker die hoorder heenwys na iets; 
(ii) dat taal meesal gesien word as 'n sosiale verskynsel wat ontstaan het eers uit 'n gemeenskap ter voldoening aan die behoeftes aan 'n omgangsof verkeersmiddel;

(iii) die teorieë die bestaan van taal by die dier ontken-taal is ' $n$ puur menslike verskynsel.

Maar nou wil ons daarop wys dat wat hierdie teoretici by die taal as wesenskenmerke bepaal-bv. die sosiale aspek, die aspek van die simboolwaarde, dat dit 'n omgangs-, of verkeersmiddel is, en so meer,-ook van die diergeluid en dierskreeu kenmerke is: wesenskenmerke. Dus om dit kortliks te stel: geeneen van die antropogenetiese teorieë wat ons tot dusver het, bevredig nie, selfs nie die van Révész nie, die Amsterdamse psigoloog, wat die jongste is, nl. die kontakteorie. Taal is nie in die eerste plek 'n sosiale verskynsel nie, is nie taal omdat dit 'n kontakmiddel is nie. Die oorsprong en wese van die taal moet buite die gemeenskap, buite die omgang, buite die verkeer gesoek word, net soos buite die dier-en dit is in die wese van die antropos, die mens, soos hy wesensverskillend is van die animal, die dier.

Vir die bepaling van die wese van die taal, vir die vinding van sy oorsprong en die vasstelling van sy ontstaan, is die bepaling van die wese van die mens self' $n$ sine qua non: geen taal sonder die mens: die taal is uit die mens, deur die mens, vir die mens..... ás mens.

Dus is ons kernprobleem: Hoe en wat is die mens as taalmens teenoor die dier as taallose dier. Dit wil ons beantwoord deur 'n teenstellende: vergelyking tussen dier en mens.

By hierdie vergelyking wil ons die dier neem in sy vorm of gestalte die naaste aan die mens-dus die hoogsonwikkelde antropoïde aapsoort. In albei wil ons uitgaan van die pasgeborene, en selfs verwys na die voorgeboortelike of fetale stadium. Daarby wil ons wys op $A$. ooreenkomste en $B$. verskille.

A. By geboorte kom albei met 'n sekere gegewenheid van gemeenskaplike vermoëns in die wêreld: a) fisies-fisiologies-en by die fisiese sluit ons die chemiese stoflikheidsamestelling in-: been (skelet), vleis, huid, bloed, senuwees, harsings, ens.; b) organies: hartslag, bloedsomloop, asemhaling, stofwisselings-prosesse (metabolisme), klierwerkinge, organiese funksies; c) sintuiglik: gesigs-, gehoors-, reuk-, tas-, smaakorgane: die verbindingswerktuie en -kanale tussen individu en omwêreld, waar die indiwidu self teenoor homself in die omwêreld staan, daardie omwêreld ervaar, belewe, ,ondergaan' en na sy aard, volgens sy wese daarop reageer; d) erflik; i) liggaamlike, organiese erfenis-bv. kleur van oë, gelaatstrekke, kleurte- 
kening, grootte, vorm, gestalte, ens. ii) instinkte, drifte, drange, affekte, ens. ens.-alles wat bioties, vitaal gerig is op organiese behoud, liggaamlike veiligheid, instandhouding van die fisiologiese bestaan en voortbestaan van die enkeling en sy soort; instinkmatige of instinktiewe beweginge, reaksies, handelinge, gedraginge, skreeue, geluide, ens. e) bewussynlik: affektelewe, emosies (sg. laere en hoëre), gevoel; intellek, verstandelike vermoëns; strewingslewe, lewensdrang, ens.

So is die raamwerk van wonderlike, opvallende ooreenkomste in elk van die gemelde aspekte. Die ooreenkoms, die parallelisme is onontkombaar, onontkenbaar: dier en mens. Met baie reg sou mens kán (en moontlik moet!) aanneem dat die mens ' $n$ verdere ontwikkeling is van die gestalte van die dier, of dat die mens-wese ' $n$ wyere ontplooiing is van die dier-wese. En op dieselfde gronde en oorweginge die mensetaal van die dieretaal! Maar teenoor hierdie sterk, grondliggende ooreenkomste, moet ons ook die sterk, grondliggende verskille aantoon.

B. Dus die verskille:

a) fisies-fisiologies (en chemies!): die menslike liggaam bly 'n menslike, die dierlike 'n dierlike; bloed verskil: mikroskopies, chemies-reaktief; dierebloed en mensebloed nie mengbaar by mediese behandeling nie; ook geneties: kruising nie moontlik nie: geen mensesoort of -ras met dieresoort of -ras nie; vlees van mense is een soort, vleis van diere 'n ander, van visse 'n ander-dus ook senu- en harsingmaterie, in samestelling en in soort;

b) organies: ook hier verskille-vgl. voeding en voedingsoorte; voortplanting en lewensduur; afhanklikheid by geboorte, ontwikkeling;

c) sintuiglik: verskerpte sintuie by dier-vgl. Boesman, en tog die diere oortref, reaksies op en aanpassing by buitewêreld.

d) erflik: erflikheidsfaktore by diere veel sterker as by die mens: instinkte: selfbehoud, veiligheid, beweeglikheid, werksaamheid van sintuie, liggaamsvermoëns (vgl. die supermens Tarzan!!)

e) bewussynlik: hier is die verskille baie groot: dier gouer volwasse, vermoëns gouer ontplooi; maar so héél anders: mens verstaan so heel anders, voel, leef affektief en emosioneel so heel anders; strewe en daadlewe is so heel anders; reaksies teenoor omwêreld, handelinge, gedraginge is so anders, belewing van die omwêreld in wese só heel anders en die verhouding van die mens tot sy ervarings- en belewingswêreld só heel anders, dat by die mens iets moet wees wat nie by die dier is nie, nie 'n blote graduele andersheid nie, maar 'n fundamentele wesensverskil. 
Om saam te vat: sowel dier as mens het ' $n$ fisies-fisiologiese of stoflikvitale, 'n organies-sintuiglike, 'n somaties-bewussynlike bestaan, met wonderbaarlike ooreenkomste-hulle staan dus sonie eensoortig by mekaar nie of chronogeneties opmekaar, dan tog gelyksoortig langsmekaar. Dienooreenkomstig is daar by albei sintuiglik-bewussynlike ervaring van die omwêreld deur die organies-sintuiglike kanale van die liggaam; daar is instinktiewe lewensuiting met opvallende ooreenkoms, so-ook emosionele of affektiewe lewensuitinge, die ooreenkoms waarvan niemand kan ontken of verontagsaam nie: die dier het, soos die mens, sogenaamd 'n gevoelslewe, 'n denklewe en 'n strewingslewe. Wat die verskille betref sou hulle dan slegs gradueel wees: by die mens sou alles dan net verder ontwikkel wees, meer gespesialiseer; by die mens sou die ewolusie van die bewussyn voltrek wees-sy dit dan ook slegs self 'n stadium tot 'n nog verdere, hoëre ontwikkeling. Laat die ooreenkomste wees wat dit wil, laat die verskille t.o.v. sekere verskynsels slegs graadverskil wees, graduele verskille van die uiterstes-een ding bly vasstaam: daar is verskynsels by die mens t.o.v. die ervaringslewe, van die belewing van dieselfde omwêreld wat nie by die dier, selfs gradueel, selfs nie kiemmatig voorkom nie. Hierop kan ons nie in besonderhede ingaan nie. Slegs dit: die dier het geen regsbegrippe, geen regsbesef, geen regservaring; geen godsbegrip, godsbesef, godservaringe wat hy bewustelik besef of ervaar nie; geen kunsbesef of kultuurbegrippe nie; geen sedelikheidsbesef of sedelikheidsbegrippe, geen gewete nie. Dus geen regsbelewing, kwaad-belewing of godsbelewing nie. Nog veel meer het die dier nie. Vir die kat of hond of leeu wat hulle hele lewe deur diere sien en ervaar en eet, is die gesiene, ervare, geëte diere tog iets heel anders as vir die mens wat dieselfde diere sien, ervaar en eet! Vir die mens is die pampoen of mielie of grondboontjie tog iets heel anders as vir die slimste en geslepenste bergbobbejaan! Dis nie 'n graduele verskil in begrip of voorstelling of wat ookal nie-dis 'n wesensverskillende iets: omdat die mens wesensverskillend van die dier, is hierin nl. dat die mens, ondanks somatiese en bewussynsooreenkomste, van die dier verskil in die besit van 'n bepaalde hoëre, vermoë wat ondierlik, buitedierlik en bodierlik is. En dié vermoë is die gees-dié besondere menslike vermoë wat sy emosie, sy intellek of denke, sy strewe of volisie bepaal, rig en beheers. dit het die dier nie, geen dier nie; nie eers kiemmatig nie. Die dier is in absolute sin daarsonder. Tot sy wese behoort geen geesteselement. Die gees is 'n suiwer menslike, wesensbepalende element, menslik-enig. Daarom kan dit ook nie setel in 'n sg. dierlik-menslike liggaam nie: die mens is somaties ook wesensverskillend van die dier. Ook bewussynlik ewe wesens- 
verskillend. Die dier het geen selfbewussyn, geen Ek-besef of Ek-begrip, geen persoonlikheidswese, -besef of -begrip nie.

Wat die mens bo die dier verhef, wat hom andersoortig en wesensverskillend van die dier maak, is die besit van sy menslike gees. Die mens is 'n geesteswese. Hierdie gees setel in en funksioneer deur die menslike liggaam-dit maak die mens, die taalmens, dus 'n geestes-somatiese wese. Dis kragtens sy gees dat die mens 'n selfbewussyn, 'n Ek-besef en 'n Ekbelewing het, 'n indiwidualiteit, 'n persoonlikheid. Die gets is nie produk van die mens se stoflik-biotiese of stoflik-vitale bestaan nie, nóg is dit bloot die produk van die mens se senuwerksaamheid of van sy harsingprosesse nie. Die somatiese mens het nie self sy gees gemaak, in aansyn geroep of die ontstaan en volgroeiing tot gees bewerkstellig nie. Die gees is nie die emosie of verstand of volisie nie-ook nie die som, die produk of die resultant van die drie vermoëns nie. Die gees is 'n ander entiteit, 'n iets met 'n eie wesendheid. Dit is dié bestaanshoedanigheid waarkragtens die menslik-somatiesbewussynlike eers bo die dierlik-somaties-bewussynlike verhef word tot die volmenslike: die somaties-bewussynlik-geestelike, d.i. die persoonlike, die indiwiduele. Die lewenskiem, die lewenssaad waarmee die gees in die menslike somatiese bestaan kom, is niks anders nie as die $E g o$, die $E k$ wat God uitplant in ons somaties-bewussynlike lewensaarde: en daaruit groei ons persoonlikheid deur die werksaamheid van ons emosie, ons denke en ons wille, ineen- en deureenvloeiend met mekaar, elemente van, diensmiddels, vermoëns van die Ek-gees deur die bewussynswerksaamheid. Immers: die bewussynsvermoëns, nl. die emosie, die intellek, die volisie is nie self kreërend en selfgenoegsaam nie. Hulle is wesenshoedanighede, dinamiese diensmiddele, ontplooiing en toe-eieningskanale van die Ego. Dis die Ego wat emosioneer,wat rasioneer, wat volisioneer, dis om die ontwil van die Ego dat geëmosioneer, gedink en gestreef word.

In ons teenstelling tussen dier en mens, in ons wesensonderskeiding tussen dierwese en menswese, moet ons twee vorme van bewussynswerksaamheid, d.i. insluitende „emosionele”, intellektuele en volisionele aktiwiteite, onderskei, nl. 1. die alleen gerig op die lewensvoortbestaan, die somatiese bestaan en voortbestaan, d.w.s. alleen gerig op die instandhouding van die lewende soma self (selfinstandhouding) en van die soort, d.i. voortplanting vandie soort (soortinstandhouding). Dit kan ons karakteriseer as die aardsgebondene, die stoflik-bepaalde en stoflik-beheerste bestaan: uit en van die aarde aards, stoflik, vernietigbaar en vernietiglik, nie gerig op of bestem vir 'n hiernamaals, of 'n elders of 'n anders nie. Hierdie voele, denke en wille wat dit eintlik in wese nie is nie, karakteriseer ons dan as absoluut 
vitaal-somatiesgerig en daarvoor wil ons die term outisties gebruik. So is wat ons ook by die dier emosie noem, net gerig op en fungerend vir die voortbestaan van die self en die soort. So is wat ons by die dier denke noem en strewe noem. Dáár eindig dit: temporaal, lokaal-,organies-, bewussynlikbeperk, verganklik en vernietiglik, in tyd 'n einde, in plek 'n einde, in bestaan ' $n$ einde, in soort ' $n$ einde, in bewussynlike lewe 'n einde. Die dier is in alle opsigte in absolute sin outisties: geen kultuur, geen moraal, geen godsdiens en geen taal nie; die dier se lewe word beheers en gerig deur sy voedingsdrif en sy voortplantingsdrif.

2. Die tweede vorm van bestaan, lewe, bewussyn, ens. is anders: dis doelgerig, nie selfgerig of soortgerig nie; doelgerig buite, bo die somaself of soortself, nl. op 'n personaself, 'n persoonlikheidself, beter, voller, ryker, hoër, groter, selfs anders en elders in tyd, in plek, in ruimte, in vorm as die bewussynlik-lewende somaself. Die dier het geen besef of begrip of bewustheid van herkoms nie: somaherkoms of spesiesherkoms, van familieonderskeiding of -verwantskap nie, ook nie van 'n dergaans nie. Die mens het. Hy weet sy herkoms of wil dit weet, streef deur wetenskap en ondersoek om dit te weet: dis sy grootste probleem, dit verg en erlang sy kragtigste inspanning in Godsdiens en wetenskapsbeoefening. En daarby kom die probleme: Waarheen? Wat hierna? En waar hierna? En wie en hoe hierna? Die mens met sy voele, denke, wille is dus te karakteriseer as personisties. Daar is dus 'n onloënbare, onnegeerbare, feitelike wesensverskil tussen dier en mens: 'n verskil waarvan die gevolg is die verskil tussen 'n outistiese bestaan, bestemdheid en bewussynslewe en die personistiese bestaan, bestemdheid en bewussynslewe. Tussen mens en dier is daar die parallelisme dat die mens ook 'n outistiese bestaan en bewussynslewe het, maar nie animaal-outisties soos die dier nie, want bo die mens se outistiese staan die personistiese wat juis die outistiese personisties bepaal; beheers, en rig, sodat die mens homineel-outisties bestaan, nie animaaloutisties nie. Die dier se voedingsdrif en voortplantings- of seksdrif en ander drifte wat daarmee saamhang of daaraan ondergeskik en diensbaar is, is absoluut outisties. Die mens se drifte wat soortgelyk is aan die van die dier, en alles wat die mens analoog besit met die dier, is homineeloutisties of personisties, in wese anders as die van die dier-vgl. bv. die vreesinstink of vreesdrif.

En die gevolgtrekking lê voor die hand: as die mens dan in sy wese verskil van die dier kragtens sy besit van 'n gees of geesteswesendheid, d.i. personistiese wese, dan is die bestaan van die dinge wat alleen-menslik, puurmenslik, menslik-enig is, alleen uit en deur die werksaamheid of funksie 
van die gees verklaarbaar en begrypbaar, dié wesensgegewe wat die mens personisties maak, 'n persoonlikheid gee. Taal, spraakvermoë, spraak behoort tot die verskynsels-daarom is taal alleen verklaarbaar in terme van die gees en geesteswerksaamheid: taal is primêr 'n geestesproduk, 'n geestesskepping, vrug van die gees se werksaamheid, van die gees se funksie. Maar gees is iets anders as menslike bewussyn, iets bo en buitekant die bewussyn: dis iets in die menslike wesensgeheel, die persoonlikheid waartoe sowel liggaam as bewussyn behoort, maar in diens waarvan sowel die bewussyn as die liggaam staan deur die sintuiglik-bewussynlike. Ons sal dit só wil stel: die gees is die wesensvervolmakende, wesensbepalende gegewe in die menswese, gestel in sy omwêreld, sy lewensuniversum, waarmee dit in kontak gestel word deur sy personistiese bewussyn wat setel in en funksioneer deur senugestel (harsings ingesluit) soos gestel in en versprei deur die liggaam as draer van die sintuie. Die mens is dus, analities gesien 'n somaties-sintuiglikbewussynlik-geestelike wese; en kragtens hierdie personistiese wesendheid besit hy spraakvermoz̈, taalvermo:, beskik by oor spraak en oor taal, (watter verskil ons hiertussen ook al wil maak), en is die mens ' $n$ taalwese. Maar meer: nie alleen kragtens die wesendheid nie, maar ook óm die wesendheid: die spraakbesit, die taalbesit is 'n bestaansnoodwendigheid, 'n wesensnoodwendigheid van die mens, nie 'n verworwe of ontwikkelde vermoë of kundigheid nie, nie 'n sosiale noodmiddel nie. Kieckers, en alle denkers sal hom dit moet nasê, stel dit kernagtig aldus: „Die Sprache ist ohne den Menschen nicht denkbar, der Mensch nicht ohne Sprache." Daar is in die ganse kosmos, soos dit in stof, in tyd en in ruimte ingebind is, 'n enige taalwese - en dit is die mens..... omdat hy geesteswese, personistiese wese is.

En hiermee het ons nou voor die vraag te staan gekom: Hoe ontstaan die taal?

Die mens is in sy lewensuniversum waartoe hy self behoort, ingeskakel deur sy sintuie: die sintuie is sy kontakmiddels met die dinge, verskynsels, gebeure om ..... en in hom; hulle is die toevoerkanale van sy buitewêreld tot sy ,binnewêreld”, langs die sintuiglike senubane na die sentrale harsingof breinsentrum met sy verskillende sintuigsentra. Deur die psigologiesbewussynlike prosesse van gewaarwording, waarneming, assosiatiewe werksaamheid langs die betrokke senubane, ontstaan indrukke, voorstellinge, beelde, e.s.m. Deur die funksionering van die senuwees en harsings tree die bewussyn deur die bewussynsvermoëns nl. die emosie, die intellek, die volisie in funksie-maar bewussyn is nie bloot die meganiese werksaamheid van die harsings nie, of die harsings in funksie nie-bewussyn is vir ons 'n be- 
gaafdheid, 'n vermoë, 'n gawe, andersoortig as harsingmaterie-in-funksic, of andersoortig as die werksaamheid van die harsingselle. Die bewussyn soos saamgestel uit die samestellende, onderskeibare maar nie skeibare elemente: die emosie, die intellek, die volisie, is die ontplooiingskanaal, die werkingsmiddel, die diensmiddel, die aanvoerings- en verwerkingsapparaat, die toe-eieningsgereedskap vir die Ek-persoonlikheid van die ervaarde en beleefde uit die omwêreld. Die outistiese bewussyn ervaar net, dit beleef nie. Die mens word personisties sy omwêreld bewus in die verskyningsvorm en verskyningswesendheid daarvan deur sintuiglik-bewussynlike ervaring en geestelike belewing. Vir die outistiese dier is die vitaalgerigte ervaring genoegsaam, vir die personistiese mens nie. Die mens moet sy bewussynservaring personisties verwerk, be-lewe, d.i. ,vergeestelik", uitstort uit die sintuiglik-bewussynlike in die personisties-geestelike in, omskep tot ,vergeestenisse". Dit geskied nie by die dier nie. Die dierervaring het vir die dier geen ,betekenis" nie, dit het slegs outistiese, d.i. vitaal-waarde. „Betekenis” kan die ,ervaring” eers kry deur die proses van ,personistiese belewing", dit is: deur die proses van ,vergeesteliking” vau die ervaring, omskepping van die ,ervarenisse" tot ,vergeestenisse". Dit geskied deur die funksionering van die mens-eie vermoëns van personistiese emosie, personistiese intellek, personistiese volisie deur hulle ineenen deureenvloeiende, wedersyds-saambelewende werksaamheid as werkingsmiddele, toe-eienings- en verwesenlikingskanale van die Ek-persoonlikheid. Daarom het die mens ook 'n selfbewussyn en is sy hele bestaan enig en al gerig op selfverwesenliking.

Dis hierom en hiertoe dat die mens personisties ,voel”, geestelik voel, personisties emosies belewe, affektief lewe, belewe, ervaar-die dier nie; die mens kan sy hele gevoelslewe, affektelewe sover dit bewussynsbepaald en -gerig is, vergeestelik, bo die sintuiglik-sensoriese uitstoot en vergeestelikte gestalte gee; dit behoort tot die wese van die gees om dit te kan doen. Nog meer; die mens kan die ervaarde, die beleefde verstaan, rasioneel begryp, verwerk, ,denkend" daarmee werk-die dier kan nie; die mens kan die deur die verstand, die denke ervaarde, beleefde, verwerkte weer ,vergeestelik", personisties-intellektueel uitstoot en vergeestelikte gestalte gee. Dit behoort tot die wese van die gees om dit te kan doen. En eindelik: die mens kan eweneens en eweseer sy sintuiglik-bewussynlike ervarenisse en belewenisse personisties-volisioneel skeppend vergeestelik. Dit behoort tot die wese van die gees om dit te kan doen. Maar hierdie emosionele, rasionele en volisionele, ,vergeesteliking" geskied nie afsonderlik nie: dis 'n totale, 'n eenheidsbelewing, hetsy dan soms sterker gekleur, geaksen- 
tueer deur een of ander van die vermoëns. In hierdie eenheidsvorm neem die ervarenisse en belewenisse deur die vergeestelikingsproses die gestalte aan van ,vergeestenisse"-dis wat ons in verouderde taal onderskei as „,betekenis”. Die proses is dit: sodra die ervarenisse en belewenisse van die omwêreld, wat tog altyd in mindere of meerdere mate kompleks is, ,,vergeestelik word", personisties verwerk en ,toegeëien” word, dan word hulle ,,losgemaak" van die werklikheid, uitgelig of uitgestoot uit die sintuiglik-bewussynlike bestaan in die personisties-geestelike bestaan; hierdie „,vergeestelikte bestaan" transsendeer die stoflik-sintuiglik-bewussynlike bestaan en neem 'n suiwer ,geestelike" vorm aan as ,vergeestenis". So word dit self vir die personistiese bewussyn 'n gewaarwordings- en waarnemingsobjek. Maar as ,,vergeestenis" het dit nog geen belynde, omlynde, konkrete gestalte nie. Dis nog vaagomlynd, vervlugtigend, in 'n mate nog amorf, onhanteerbaar as ,vergeestenis". Dis vir die somaties-sintuiglikbewussynlike mens ontoeganklik, ongenaakbaar. Die ,vergeestenis" moet dus om vir die personistiese wese self genaakbaar, toeganklik en hanteerbaar te wees 'n nie-geestclike gestalte aanneem of omgeskep word tot of in 'n konkrete, personisties hanteerbare vorm. Hierdie omskepping of inskepping in 'n hanteerbare vorm, of hierdie ,vormgewing" van die ,,vergeestenis" in sintuiglik-bewussynlik waarneembare, ervaarbare en beleef bare materiaal, is 'n bestaansnoodwendigheid van die ,vergeestenis" self. Die voldoening daaraan resulteer in die ontsluiting van die mens se geesteswêreld vir homself en vir andere, in die toeganklikmaking tot die inhoud van die gees en in die ontwikkeling van 'n middel tot selfverwesenliking. Vormgewing, vergestalting, konkretisering is 'n bestaansnoodwendigheid, dis van primêre, fundamentele belang.

Die probleem is nou in watter materiaal geskied die vormgewing, die vergestalting en hoe geskied dit?

Daar is slegs twee moontlikhede: 1. die gees sou die materiaal of middel uit homself kan haal. Behalwe dat soiets vir die mens self ondenkbaar is, sou dit dan tog nog ,,geestelik", dus amorf en a-materieel, onstoflik en steeds onhanteerbaar wees; en 2. die gees kan dit haal uit sy omwêreld of uit en deur dit waarin dit self setel en funksioneer, d.w.s. uit en deur die personistiese somaties-sintuiglik-bewussynlike mensbestaan. Dit is dan ook die enigste moontlikheid. En dáárom het die mens ook die vermoë en die wesenstoerusting dáárvoor. Daaróm en daardéúr is hy mens, personistiese wese. Die vermoë is die ,Woord"- of ,taalskeppingsvermoë" en die daarmee saamhangende ,spraak-vermoë". Dis nie ,verworwe" vermoëns nie; 'n self-ontwikkelde toerusting of 'n uitvindsel om ook op die wyse ,sy 
gevoelens en gedagtes te openbaar" of "uit te druk" nie; dis nie die toevallige of willekeurige bewerktuiging van vir ander lewensfunksies bestaande organe om aan ontstane en ontwikkelde sosiale behoeftes van omgang, verkeer, kommunikasie of kontak te voldoen nie. Die somatiessintuiglik-bewussynlik-personistiese struktuur van die mens is sodanig, omdat hy mens is, met sy plek in die kosmos, met sy taak en sy bestemming in tyd en in ruimte, dat hy taal moet hê, en daarom taal het. Hy maak, skep die taal self kragtens sy personistiese wesendheid. Die enigste moontlike materiaal, fisiese materiaal waarin hy, nie dit kan doen nie, maar gestruktureer is om dit te doen, bestem is om dit te doen, dit moet doen, is ..... die taalklank ..... nie bloot fisiese klank soos deur fisiese dinge veroorsaak, of soos die windgeluid of die donder, of soos geluide, skreeue of klanke van diere nie. Dis nie ,nagebootste" klank van elders vandaan nie: die taalklank is ,klank" wat die personistiese, taalskeppende wese self skep, self formeer, self bepaal kragtens sy taalvermoë in die dáárvoor bestemde spraaksentrum van sy harsings. Die ,taalklank" is materie, fisiese materie gevorm uit sy eie lewensadem deur die taalwerksaamheid van die betrokke senu- en harsingmaterie wat deur die ,skeppende gees" bewerktuig word om juis dié ,gestalte", die „gekonkretiseerde vorm” aan die vergeestenis te gee. Daarom is die ,geskape woord", die in klank gekonkretiseerde vergeestenis altyd artikuleerbaar. Dit kry nie eers klankgestalte deur, met of by artikulasie deur die spraakorgane of wanneer dit akoesties waarneembaar is nie-maar vergestalting van die „,vergeestenis" in „klankmateriaal" gaan artikulasie vooraf. Dit moet, dit kan nie anders nie. Die ingieting van die ,vergeestenis", die vormgewing daarvan in die fisiese materiaal van die taalklank, d.w.s. die taalmatige konkretisering, drabaar-, bewaarbaar- en hanteerbaarmaking van die vergeestenis: dis die woordskepping, woordmaking. Hierdie gekonkretiseerde klankgestalte van die vergeestenis-dis die woord, die primêre element van die taal. So ontstaan taal, selfs in sy primitiefste vorm; so ook by die kind. So is sy oorsprong. En hierin lê sy wese bepaal: dis die middel, nie primêre middel of ook 'n middel nie, maar die wesensbepaalde, wesensenige middel wat die personistiese wese spesifiek kragtens sy wesensvermoëns oor beskik om sy amorfe vergeestenisse mee te vorm, in te vorm, drabaar, bewaarbaar en hanteerbaar te maak: bruikbaar vir die velerlei funksies waarvoor hy die taal as vormgewing van sy vergeestenis nodig het. In die also ontstane en aldus geskape woord ontmoet die wêrelde van gees en materie, van gees en stof mekaar. Deur en in die ,woord", die „taal”, skep die mens sy ervaringsdinge om tot sy geestelike besit, geestelike inhoud, geestelike rykdom. Eers in die,,woord" 
kry die ,vergeestenisse", hoe kompleks ook al, hulle belyning, hulle vorm, hulle helderheid, hulle begrypbaarheid, dus hulle linguale waarde. In die woord is inhoud (vergeestenis) en vorm (klankgestalte) 'n eenheid. Die vergeestenis is sowel emosioneel as intellektueel en volisioneel bepaal: dis die vergeestelikte ervaringsgeheel. Dit is die inwendige woordvorm, wat alleen deur die uitwendige, die klankvorm waardeur dit vorm $\mathrm{kry}$ en waarin dit gedra word, genaakbaar, waarneembaar is. Dis die inwendige wat aan die ,woord" sy bestaan verleen. Die uitwendige is slegs materiaal, is slegs middel, daarom het dit bloot funksionele waarde. Die taal self is ewe-eens slegs ' $n$ middel, 'n instrument vir die bewussynlik-geestelike aktiwiteite van die mens as personistiese wese. Die waarde en betekenis en vorm van die taal word bepaal deur die funksie of funksies waarvoor en waartoe dit gebruik word. Om dié personistiese funksies te verrig moet dit bestaan en het dit ontstaan-daarom karakteriseer ons die beskouing as die funksionele taalbeskouing of taalteorie. Dit gaan uit van die wese van die mens, daarom is dit die suiwerste antropogenetiese teorie.

F. J. LABUSCHAGNE. 